深層混合処理工法による改良体の品質評価法

\title{
A SYSTEM TO EVALUATE THE QUALITY OF SOIL-CEMENT COLUMN BY DEEP MIXING METHOD
}

\author{
田村昌仁*1, 井上芳生*2, 小堀隆治*3, 渡辺一弘*4, 藤井 衛*5 \\ 日比野信一*6, 小川能克*7, 牧原依夫*8, 阿部秋男*9 \\ Masahito TAMURA, Yoshio INOUE, Ryuji KOBORI, Kazuhiro WATANABE, Mamoru FUJII, \\ Shinichi HIBINO, Yoshikatsu OGAWA, Yorio MAKIHARA and Akio ABE
}

\begin{abstract}
This paper deals with the system to evaluate the quality of soil-cement column made by deep mixing method. Through the field tests on the several kinds of evaluation methods, main conclusions were summarized as follows. 1)Fundamental index to evaluate the quality is the uniaxial compressive strength of the column by random sampling. 2) The electric resistivity tests to evaluate the mixing degree in the unsolidified condition immediately after the construction, the test method to determine the ratio of unmixed soil parts to the total cross section area in the horizontal cutting surface, and also the integrity tests to evaluate the structural soundness of column are useful to make the standard quality based on the strength of core specimens randomly sampled.
\end{abstract}

Keywords : ground improvement, soil cement, deep mixing method, quality evaluation, foundation, field tests 地盤改良、ソイルセメント、深層混合処理工法、品質評価、基礎、現場実験

\section{1. 目的}

深層混合処理工法は、土と固化材を現位置で䚓䢁混合する工法であ り、改良体の品質は地盤条件や施工条件によって大きく異なる。この ため、設計で想定する品質の設定方法や改良効果の確認方法が重要で、 信頼できる改良体の品質評価技術が必要不可欠である。

改良体の品質評価に関しては、靦汼性能の評価が最も重要であり、 工法毎に独自性を有する摫汼翼などの靦汼条件を考虑し施工機械毎・ 施工方法毎に評価することが必要である 1)。設計者は、採用する工法 の施工品質を要求性能との関係に照らして的確に評価しなければなら ない。しかし、調查法、評価法、地盤の違いによっても、評価結果が 異なる可能性があるので、同一条件下で様々な調査等を実施し、評価 法の信頼性や適用範囲を明確にすることが重要である。

今回は、同一条件下で施工された改良体に対して、従来のボーリン グコアによる一軸圧縮強さだけでなく、電気比抵抗による未硬化段階 の摫汼混合状況の評価、改良体に含まれる土塊混入状況の評価、イン テグリティ試験による評価など、様々な手法を用いて改良体の品質を 調查し、各種試験・評価方法の適用性や相互の関連性などを検討した のでその結果を述べる 2)。また、併せて改良体に必要とされる品質な どに関して考察する。

\section{2. 改良体に対する要求性能}

改良体に必要とされる基本要求性能は鉛直支持性能であり、コラム （柱状の改良体 1 本）の耐力を考えた場合、コラムの設計基準強度 $F_{c}$
はコラム 1 本の鉛直耐力（度）と同程度以上に設定することが必要で ある。同一現場における実大コラム強度 $\mathbf{Q}$ に対して、平均圧縮強度 Qave、標準偏差 $\sigma_{c o l}$ とすると、 $F_{c}$ は(1)式で与えられる。実大コラム強 度はコア強度の平均值とコア強度の標準偏差などから(2)式で与えら れ、Q=Qave として $F_{c}$ とコア強度の関係を求めると(3)式になる。文 献 1)では、多数の実験結果の平均值として(2)式の $m=1.3$ が示されて いる。なお、コラムやコアの強度は、同一地層の改良部分を対象とし ている。

$$
\begin{aligned}
& F c=\text { Qave }-k \cdot \sigma c o l \\
& Q=q u f-\boldsymbol{m} \cdot \sigma c o r
\end{aligned}
$$

$F_{c}$ : コラムの設計基準強度 Qave : コラム強度の平均值 $\sigma \mathrm{col}$ : コラム強度の標淮偏差 $\mathbf{Q}$ : コラム強度（実大強度） $q u f$ : コア強度の平均值 $\quad \sigma c o r:$ コア強度の標隻偏差 $k, m:$ 係数

$$
\begin{aligned}
& F_{c}=q_{u f}-\beta \cdot \sigma_{c o r} \\
& \beta=\frac{k V_{c o l}+m V_{c o r}\left(1-k V_{c o l}\right)}{V}
\end{aligned}
$$

$\beta$ : 係数 $V_{c o r}$ : コア强度の変動係数 $V_{c o l}:$ コラム強度の変動係数 (3)式の $\beta$ 值は、(4)式で与えられ、コア強度やコラム強度の変動俰数と の関係でみると表 1 となる。コラムは構造体でなく地盤であり、 $k$ の 值として 0.5 1 でも支障ないと考えると、コア強度やコラム強度の変 動係数が 20 30\%程度の範囲における $\beta$ 值は概ね 1.5〜2.4 となる。

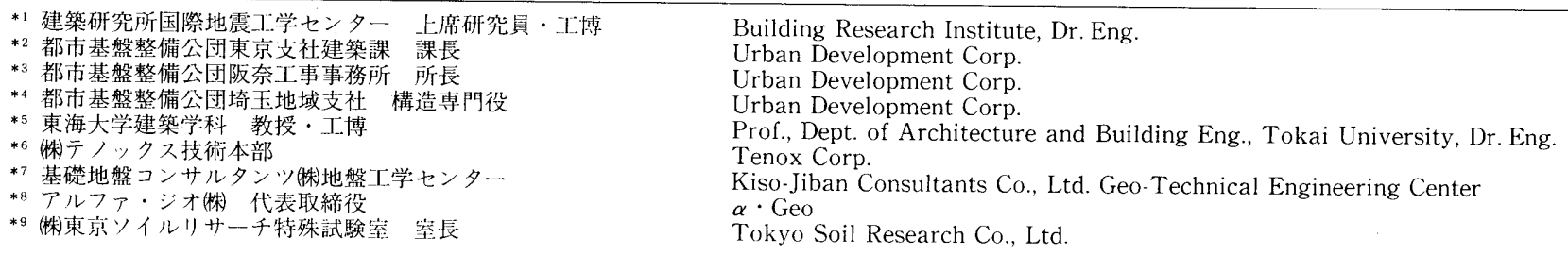


$\beta=2$ の場合、 $F_{c}$ に対する コア強度の不良率は $2.3 \%$ と なり、 $\beta=2$ が実現されてい るコラムからコアを数多く 採取した場合、想定した品質 が実現されているかどうか の条件は(5)式で表される。 このため、コア強度による合 否判定基準は、その変動係数 を $20 \sim 30 \%$ とすると、 $q_{u b}>$ $q_{u b} \geq F c+2 \sigma_{\text {corb }}$ $q_{u b}$ : 採取したコアの平均強度、 $\sigma_{\text {corb }}$ : 採取したコア強度の標準偏差

コア強度の変動係数が $40 \%$ を超えても、コラムが一体として固化し、 ばらつきに応じた設計がなされていれば特に支障ないと考えられるが、 $V_{\text {cor }}$ が $40 \%$ を越えると正規分布を仮定した統計上の取り扱いが難しく なるだけでなく、 $q_{\mathrm{ub}}$ の值が(5)式より $5 \mathrm{Fc}$ 以上となり、コア強度のば らつきの幅も大きくなるので、コアの採取数が少ないと信頼できる品 質検査方法を設定することが難しい。このため品質検査に関して、今 回目標とする改良体の品質としては、 $V_{\text {cor }}$ 花概水 $30 \%$ 以下でかつコア を採取する際に無作為な採取が可能となるような固結状況を考えた。 ボーリングコアの直径が $5 \sim 10 \mathrm{~cm}$ と小さいことを考えれば、固結範囲 に含まれる未硬化な土塊の割合が大きくなると無作為なコア採取が困 難となる。このため、ボーリングコアに含まれる未硬化部分の割合に 制限を設けることが多く、文献 1)では未硬化部分の割合がコア $1 \mathrm{~m}$ 毎 に $10 \%$ 以下であることをコア強度検査が実施できる要件としている。 このようなことから、コア強度を指標としてコラムの品質を詳細に評 価するためには、土塊混入状況の評価が必要不可欠で、詳細に検討す るためには従来のボーリングコアによる深度方向の土塊混入状況だけ でなく、コラムの水平断面に対する土塊混入状況の評価が有用である。 翼抖翼の形状や摫挥方法によっては、コラム水平断面の外周部や中央 部の靦汼が不十分な場合もありうる。

\section{3. 評価項目及ひ実験概要}

改良体の基本性能評価指標は、コラム強度やコア強度による抜き取 り検査が一般的である。その強度とばらつきが正しく評価されている ことを判断するためには、土塊の混入状況がコアの抜き取り状況に影 響することを考慮すると、コラムの平面的な混ざり具合及び樑度方向 へのコラムの混ざり具合を現すコラムの連続性に関しても定量的に把 握しておくことが必要である。そこで、今回は、表 2 に示す種々の評 価方法を用いて、適用範囲や各種試験の相互の関連性などを検討する ことにした。実験は、埋土・粘土質シルトを対象とした実工事を利用 した実験 $\mathrm{A}$ と、関東ローム層を対象にした試験工事として実験 Bを行 った。特に実験 Bは、標準品質（施工時間 14 分）、低品質（施工時間 7.7 分の急速施工)、極低品質（施工時間 7.7 分の急速施工かつ共回り 防止機能のない施工）のコラムを人為的に築造して品質の比較実験を 実施した。图 1、表 3 には、コラムの標準施工仕様と施工管理基集、 柱状図等を示す。なお、品質評価の対象となったすべてのコラムに関 しては計画した施工仕様が確保されていることを梁度計・流量計・電 流計などの自動計測データにより確認しており、この確認はコラムの 品質評価を行う前提条件となる。

\section{4. 調查方法の概要}

\section{1 コア強度試倹}

コア強度は、改良体の基本性能評価指標であるため、コラム頭部だ けでなく、ボーリングコアや深部の水平切断面から多数コアを採取し て一軸圧縮強さのばらつきなどを把握することが必要である。この結 果は、他の手法の信頼性を判断するための指標となる。
表 2 改良体の品質評洒に用いた試験方法

\begin{tabular}{|c|c|c|}
\hline 詿験の種類 & 詰験方法 & 説 \\
\hline $\begin{array}{l}\text { ボーリングコア } \\
\text { による謤查 }\end{array}$ & 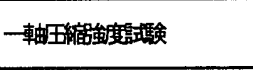 & $\begin{array}{l}\text { ボーリングコアの端面を成形・キャッピング } \\
\text { し、 田䋧相験を行う。 } \\
\end{array}$ \\
\hline \multirow[b]{2}{*}{ 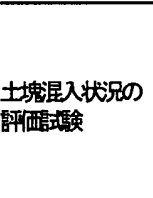 } & コア操取率铜查 & $\begin{array}{l}\text { ボーリングコア全镸こ混入する未固結の土塊部 } \\
\text { 分の割合を求める。 }\end{array}$ \\
\hline & 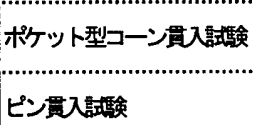 & $\begin{array}{l}\text { コラム水平哂面の未固結部分の土塊の割合を求 } \\
\text { める }\end{array}$ \\
\hline \multirow{3}{*}{$\begin{array}{l}\text { ボーリングコア } \\
\text { を利用した㔀験 }\end{array}$} & 孔内水平コ一ン貫入詿験 & 孔壁ニコーンを水平に貫入し、贯入抵抗を求め \\
\hline & ボアホール映信調查 & 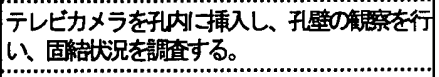 \\
\hline & 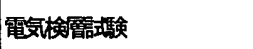 & 孔内周㲽の電気此抵抗と自然電位を測定する。 \\
\hline 非破揊硅験 & IT詰験 & $\begin{array}{l}\text { コラムのの哣部を軽打し、生じた反射波の状態さ } \\
\text { コラムの連続性を判定する。 }\end{array}$ \\
\hline \multirow{2}{*}{$\begin{array}{l}\text { 未浭化状態での } \\
\text { 調查 }\end{array}$} & 電気比抵抗調查 & 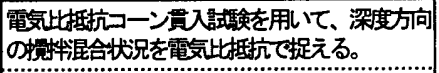 \\
\hline & $\begin{array}{l}\text { 末梗化段階のソイルセメン } \\
\text { トの採取方法 }\end{array}$ & 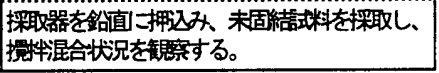 \\
\hline
\end{tabular}

\section{表 3 各実験における施工仕様と施工管理基準}

\begin{tabular}{|c|c|c|c|c|c|c|c|c|c|c|}
\hline \multirow{2}{*}{\begin{tabular}{|l} 
实 \\
験
\end{tabular}} & \multirow{2}{*}{$\begin{array}{l}=\bar{~}=1 \\
\mathrm{Na}\end{array}$} & \multirow{2}{*}{$\begin{array}{c}\text { 改良徍 } \\
6 \mathrm{~m} v\end{array}$} & \multirow{2}{*}{$\begin{array}{c}\text { 改良長 } \\
\text { (n) }\end{array}$} & \multirow{2}{*}{$\begin{array}{l}\text { 添嗮 } \\
\left.\mathrm{kg} / \mathrm{m}^{3}\right)\end{array}$} & \multirow{2}{*}{$\begin{array}{l}W / C \\
(\%)\end{array}$} & \multirow{2}{*}{$\begin{array}{c}\text { 練欧展 } \\
\text { (n) }\end{array}$} & \multicolumn{3}{|c|}{ 速度 (6/分) } & \multirow{2}{*}{ 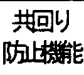 } \\
\hline & & & & & & & 掘進持 & 弓時 & $\begin{array}{l}\text { 練速持 } \\
\end{array}$ & \\
\hline \multirow{3}{*}{ A } & 1 & \multirow{3}{*}{1300} & \multirow{3}{*}{11} & 250 & \multirow{3}{*}{60} & 1.0 & 0.5 & 1.0 . & 1.0 & 有以 \\
\hline & 2 & & & 250 & & 1.0 & 0.5 & 1.0 & 1.0 & 有り \\
\hline & 3 & & & $\begin{array}{l}300\left(\mathrm{H}^{*}\right. \\
400(\mathrm{~T})\end{array}$ & & 4.0 & 0.4 & 1.0 & 1.0 & 有以 \\
\hline \multirow{3}{*}{ B } & 1 & \multirow{3}{*}{1200} & \multirow{3}{*}{4} & \multirow{3}{*}{350} & \multirow{3}{*}{60} & 1 & 0.4 & 1.0 & 1.0 & 有り \\
\hline & 2 & & & & & 無L & 0.7 & 20 & 無 & 有り \\
\hline & 3 & & & & & \begin{tabular}{|l|} 
無L \\
\end{tabular} & 0.7 & 20 & 無L & 無L \\
\hline
\end{tabular}

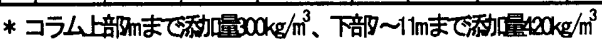
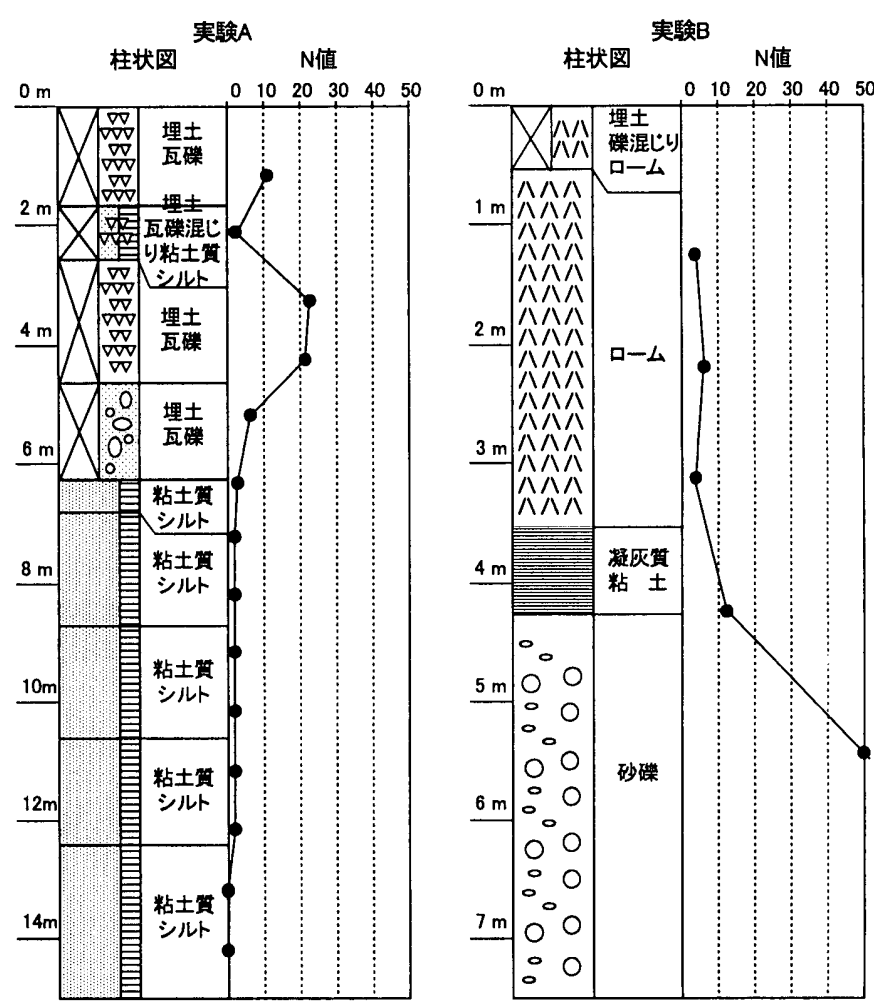

图 1 実験 A、Bにおける地盤状況 


\section{2 電気比抵抗謂査}

電気比抵抗測定は、地下水調查法などとして広く用いられているが、

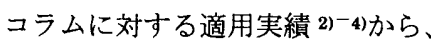

(1)セメント量が $1 \mathrm{~m}^{3}$ あたり $100 \mathrm{~kg}$ 以上の割合でほぼ均一に靦拌さ

れていると比抵抗が $(0.1 \sim 8) \Omega \cdot m$ を示す。

(2)比抵抗のばらつき・変化が大きいと翼拌が十分でない。 などを見出した。この測定による改良体の品質評価の対象は改良体の 連続性の評価であり、今回は、比抵抗値のばらつき・変化を指標とす る定量的な品質評価法を検討することにした。測定は、4 個の電極が 取り付けてある比抵抗コーン（图 2）を末硬化段階の改良体に圧入し ながら、連続的に比抵抗值を測定するものである。コーン貫入速度は 毎秒 $1 \mathrm{~cm}$ とし、測定間隔は 5〜10cm 間隔とした。

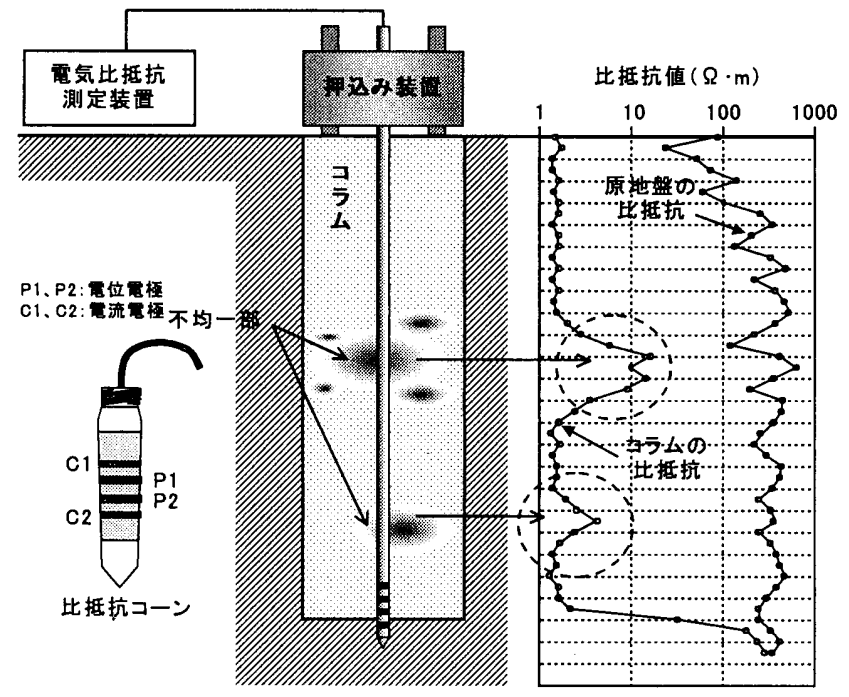

图 2 電気比抵抗調査概要

\section{3 電気検層試倹}

電気比抵抗測定は未硬化段階の評価を目的としているが、電気的性 質を指標とする硬化後の評価の可能性を調査するため、ボーリング孔 を用いて電気検層試験を行った。電気検層試験は、图 3 に示すように、 ボーリング孔を用いて地層の比抵抗や自然電位を測定する試験で、電 極間隔が $0.25 \mathrm{~m} 、 0.50 \mathrm{~m}$ 及び $1.0 \mathrm{~m}$ を標準とするノルマル検層と $2.5 \mathrm{~cm}$ 、 $5.0 \mathrm{~cm}$ を標準とするマイクロ検層がある。測定はボーリング孔内にゾ ンデを挿入し、各検層を連続的に行った。

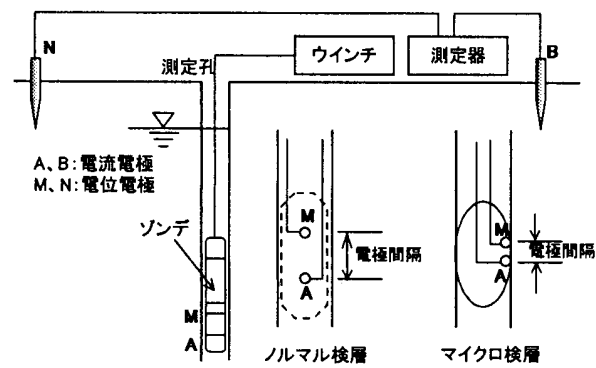

图 3 電気検層調查概要

\section{4 孔内水平コーン貫入試験}

改良体からサンプリングした試料に亀裂・ひび割れ、断面欠損があ ると、強度確認用の試料が確保できないことがある。この場合は、
一軸圧縮試験によるコア強度の評価が困難なので別途の方法で品質を 評価しなければならない。ここでは、ボーリング孔の壁面を利用した 孔内水平コーン貫入試験を実施して改良効果を確かめることにした。 試験は、図 4 に示すように、外形 $\phi 64 \mathrm{~mm}$ 、長さ $460 \mathrm{~mm}$ のゾンデを 孔内に挿入し、所定梁度で孔壁に垂直にコーンを圧入して、その時の 押寸圧力と貫入量から貫入抵抗 $q_{e 0}$ を求める試験 11) である。室内実験 で一軸試験と同じ装置を用いて囲りを拘束し、上方からコーン円錐を 貫入させて、ソイルセメントに対する適用性を調べたところ、コーン 貫入抵抗 $\mathrm{q}_{\mathrm{c} 0}$ と一軸圧縮強度 $\mathrm{q}_{\mathrm{u}}$ には 6 8 倍の相関関保（图 4 右参照） があり、 $\mathrm{q}_{\mathrm{c} 0}$ を改良体の強度指標として用いることにした。
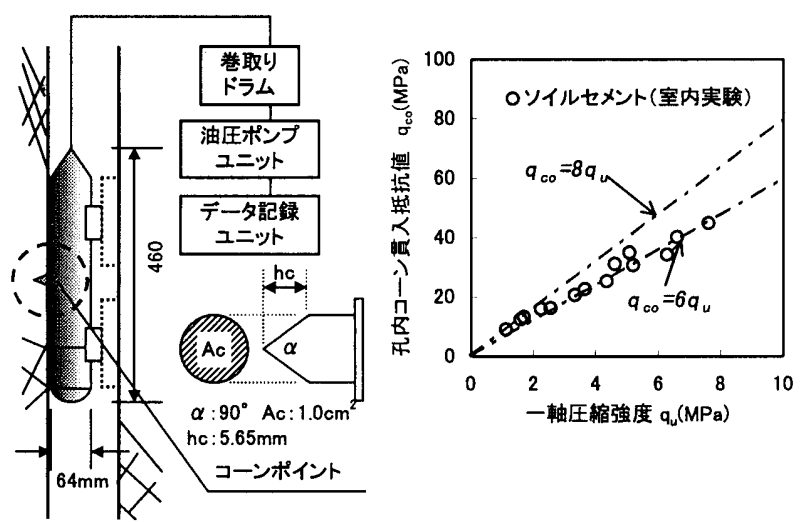

\section{图 4 孔内水平コーン調査概要}

\section{5 ボアホール映像謂查}

孔壁の出来映えを目視確認することができれば、局所的に介在する ガラなどが原因でコア強度の確認が困難な場合や強度が予想外に不足 している場合の原因・対策を考える上で有益である。今回は、ボア木 ール映像調查法 ${ }^{5}$ を用いて、ボーリング孔の壁面の映像を確認寸るこ とにした。图5は、装置概要である。

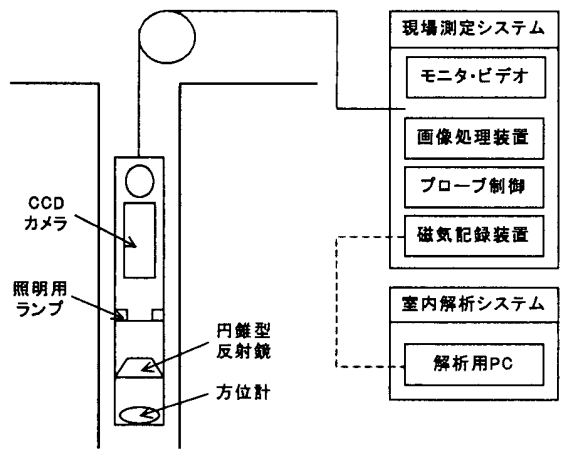

图 5 ボアホール映像謂査概要

\section{6 土塊湿入状況の評価試倹 6)}

改良体に土塊が多く含まれると、無作為なコア採取が困難となり、 コア強度による品質評価の信頼性が低下する。このため、コラムに含 まれる土塊量の情報に基づいた強度や連続性の評価が重要である。

土塊混入状況に関しては、フェノールフタレイン溶液をボーリング コアやコラムの水平切断面に塗布する方法があるが、土塊部分でも赤 色反応が見られることがあり、信頼性は必ずしも十分でない。写真 1 は、コラムの切断面にフェノールフタレイン液を塗布したものである が、指圧により明らかに土塊と判断される部分であっても赤色反応が 認められた。土塊の大きさや土塊中の土粒子の大きさにもよるが、 
硬化するまで土塊は泥状の混合部分と接触するため、間隙水の $\mathrm{pH}$ が高くなることなどが原因と考えられる。

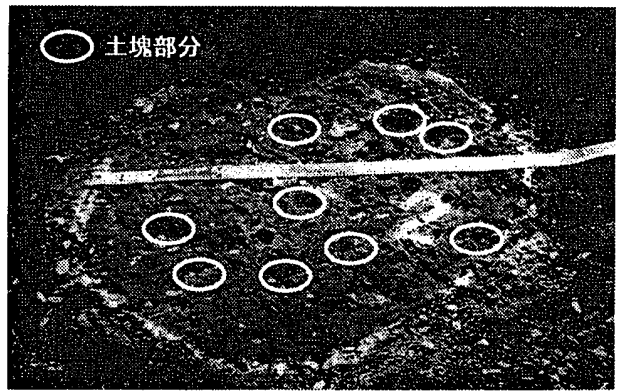

注）目視・指圧等で確認した土塊部分も赤色反灿を示す。

\section{写真 1 フェノールフタレイン涴液による} コラム水平断面の土塊湿入状況

(1)コア採取率調查

コラムの連続性の評価として、コア採取率を指標として用いて検討 した。コア採取率とは、ボーリングにより採取したコアから土塊部分 を除いたコア長を採取長で除して得られるものであり、コア断面に対 して土塊及び末硬化状態である固化断面欠損の割合が概ね $50 \%$ 以上 の場合を土塊部分 ${ }^{1)}$ と判定した。また、(100-コア採取率) を土塊混 入率として評価する場合もある。图 6 にコア採取率による評価法を示 す。

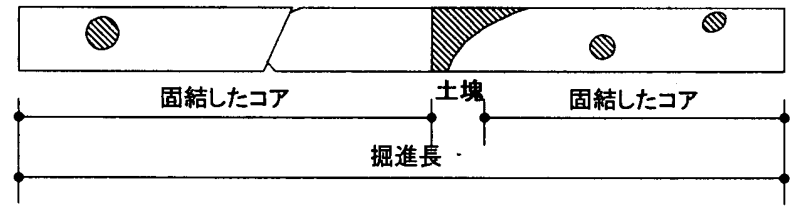

图 6 コア採取率による棓価法

(2)ポケット型コーン貫入試験

ポケット型コーン貫入試験は、コラム水平断面の土塊混入率の評 価を目的としている。施工後 1 週間程度経過したコラムをバックホウ

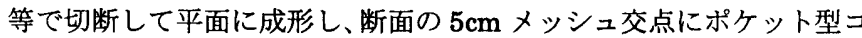
ーン貫入試験機（最大押込み抵抗力 $100 \mathrm{~N}$ 、图-7a 参照）を用いて貫入 抵抗を測定した。この方法では、貫入抵抗值「100N 未満」を土塊部 分、「100N 以上」を固結部分、さらに不整形で測定困難な測点を測定 不能部分に区分した。土塊混入率は、全測点数から「測定不能」の測 点数を差し引いた測点数と「100N 未満」の測点数の割合とした。貫 入抵抗值が $100 \mathrm{~N}$ のコーン貫入抵抗 $q \mathrm{c}$ は $500 \mathrm{kN} / \mathrm{m}^{2}$ であり、粘性土の

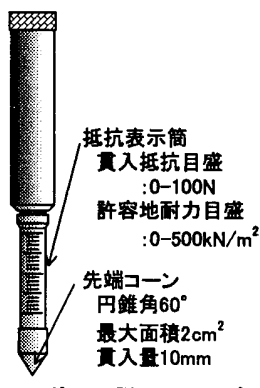

a) ポケット型コーンタイプ

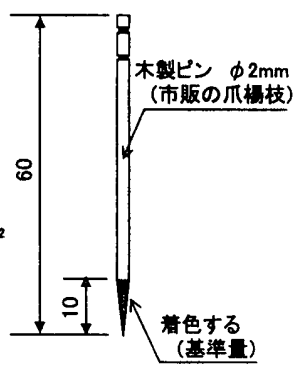

b) ピンタイプ
图 7 ピン貫入試酫用測定器 $\mathrm{qc}$ と一軸圧縮強度 $\mathrm{qu}$ との一般的な関係 ( $\mathrm{qc}=5 \mathrm{qu}$ 前後) から判断する と、 $100 \mathrm{~N}$ で貫入できるソイルセメントの強度は概ね $100 \mathrm{kN} / \mathrm{m}^{2}$ 以下 であると考えられる。

\section{(3)ピン貫入試験}

この試験は、コラム断面にピン（爪楊枝、图-7b 参照）をポケット

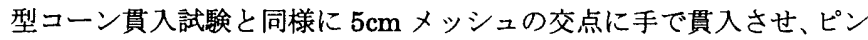
が $1 \mathrm{~cm}$ 以上貫入した場合を土塊、 $1 \mathrm{~cm}$ まで貫入しなかった場合を改 良体と判断し、コラム断面に突き立ったピン本数の割合を土塊混入率 とした。ピンが $1 \mathrm{~cm}$ 以上貫入するソイルセメントの強度は、室内試験 で調査したところ、概ね $100 \mathrm{kN} / \mathrm{m}^{2}$ 以下であった。

\section{7 I T 試駼}

IT 試験は、硬化したコラムの頭部に加速度計を設置した後、ハンマ 一で頭部を軽打して弾性波を発生させ、弾性波の反射性状を解析して コラム長や弾性波速度から評価する手法である。この手法は、基礎杭 の健全性調查として実績が多いが、今回はコラムを対象とした墚度方 向の連続性の評価を目的として実施した。图 8 に測定方法を示す。IT 試験でコラムの品質評価 1)を行うには、コラム長や弾性波速度のいず れかを初期値として与える必要があり、ここでは、改良長は施工記録 通りであると仮定した。これまでの実績から判断すると、この手法の 適用範囲は、コラム強度が $1 \mathrm{MN} / \mathrm{m}^{2}$ 以上、改良長が $4 \mathrm{~m}$ 程度以上と考 えられる。

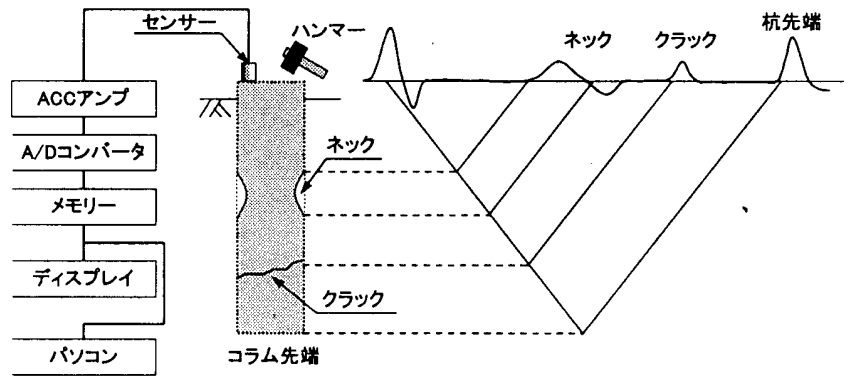

图 8 IT 試験桭要

\section{8 末硬化段降のソイルセメントの操取手法}

末硬化段階のソイルセメントの採取は、

(1)兽拌混合状況を施工直後に確認すること

(2)強度を簡便に早期に確認すること

を目的として行われる。(1)の場合には、コラム施工直後にサンプラ 一を地中に押込み、深度方向の試料を数 $\mathrm{m}$ にわたり採取する。採取装 置は試料土を乱すことなく採取できるように工夫されており、試料を 目視確認することにより、土塊の混入状況、コラムの深度方向の連続 性などを施工直後に評価できる。
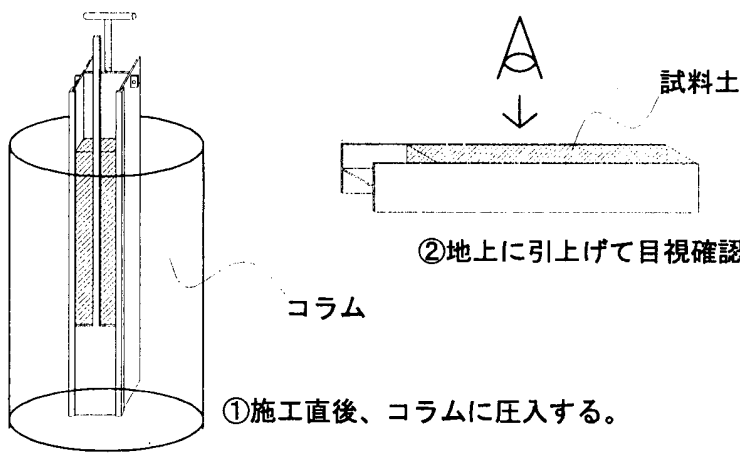

(2)地上に引上げて目視確認する。 コラム

(1)施工直後、コラムに圧入する。 
(2)場合には、直径 $10 \mathrm{~cm}$ 、高さ $20 \mathrm{~cm}$ 程度の採取器を用いて試料 を採取する方法 クが実用的である。採取した試料をモールドに充填し て供試体を作製し、早期強度を確認することが可能である。今回は、 摫拌混合状況の確認を目的として、図 9 に示寸採取装置を用いて採取 した。

\section{5. 実験結果}

5. 1 コア琴度試検

各実験におけるボーリングコア及び水平切断面から採取したコアの 強度試験結果を表 4 に示す。実験 A では、概ねコア採取率が $100 \%$ に 近く、同一層に対する変動係数も $30 \%$ 以下と少ないが、実験 B では No1 を除くと摜拌が不十分であることが同える。

\section{表 4 各実験におけるコア望度およびコア探取率}

\begin{tabular}{|c|c|c|c|c|c|c|c|}
\hline 实 & $\begin{array}{c}\text { コラム } \\
\text { No. }\end{array}$ & 探取位置 & $\begin{array}{c}\text { コア数 } \\
\text { (蔨) }\end{array}$ & $\begin{array}{c}\text { 平均強度 } \\
\text { (Olpa) }\end{array}$ & 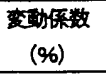 & $\begin{array}{c}\text { コア㩒取种 } \\
\text { (\%) }\end{array}$ & 㖶価区間 \\
\hline \multirow{5}{*}{$A$} & \multirow{2}{*}{1} & 頇部 & 25 & 3.13 & 18.8 & \multirow{2}{*}{97.7.} & \multirow{5}{*}{$\begin{array}{c}G-6.5 \mathrm{~m} \\
\mathrm{~s} \\
\mathrm{G}-11.0 \mathrm{~m}\end{array}$} \\
\hline & & ボーリング & 18 & 2.48 & 37.9 & & \\
\hline & \multirow{2}{*}{2} & 䫄部 & 25 & 255 & 15.5 & \multirow{2}{*}{99.1} & \\
\hline & & ボーリング & 28 & 3.14 & 59.8 & & \\
\hline & 3 & ボーリング & 31 & 9.34 & 33.8 & 100.0 & \\
\hline \multirow{9}{*}{8} & \multirow{3}{*}{1} & 頭部 & 25 & 2.70 & 10.0 & \multirow{3}{*}{96.6} & \multirow{3}{*}{$G \pm 0 m$} \\
\hline & & 中間 & 23 & 240 & 31.0 & & \\
\hline & & ポーリング & 10 & 1.40 & 21.0 & & \\
\hline & \multirow{3}{*}{2} & 酸部 & 25 & 2.00 & 17.0 & \multirow{3}{*}{72.4} & \multirow{4}{*}{$s$} \\
\hline & & 中汫 & 27 & 0.30 & 59.0 & & \\
\hline & & 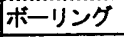 & 12 & 0.80 & 98.0 & & \\
\hline & \multirow{3}{*}{3} & 顽部 & 25 & 1.90 & 28. 0 & \multirow{3}{*}{37.3} & \\
\hline & & 中間 & 9 & 0.40 & 174.0 & & \multirow{2}{*}{$Q 2-3 . a n$} \\
\hline & & ボーリング & 11 & 0.07 & 28.0 & & \\
\hline
\end{tabular}

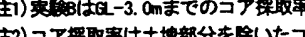

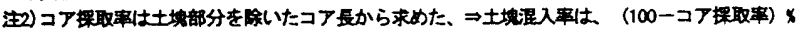

\section{2 電気此抵抗と電気検層調查}

実験 A ではNo.1において電気比抵抗測定と電気検層試験を実施し、 電気比抵抗測定は各コラムにつき 1 回の測定を行い、電気検層試験は 各コラムにマイクロ検層とノルマル検層を実施した。測定結果を图 10 に示す。電気比抵抗測定ではコラム施工前の原地盤の比抵抗とセメン トミルク原液の比抵抗測定が必要である。電気検層は、硬化後にボー リング孔を利用して測定を行ったが、孔壁の崩壊により全長にわたっ て測定できなかった。No.1におけるコラムの電気比抵抗は、原地盤の 比抵抗とセメントミルク原液の比抵抗の中間に位置し、コラム改良長 （GL-11m）を過ぎると原地盤の比抵抗に収束している。GL-6.0m ま では、カララ等を多く含んでいたためか、比抵抗がやや大きくはららつき もあるが、それ以深の改良区間では概ね一定の值を示している。

電気検首試験は、GL-8.0m までの測定であったが、ノルマル検層と マイクロ検層ではいずれも電気比抵抗調査による測定値よりもかなり 高い比抵抗を示した。これはセメントが硬化したため含水比が減少し て比抵抗が上昇したためと考えられる。ノルマル検層は、マイクロ検 層に比較して測定間隔が大きくコラムと地盤の境界などの影響も受け やすく、品質評価法としては信頼性が低い。マイクロ検層は、測定間 隔が小さく、ノルマル検層と比較するとやや信頼性があるが、作業効 率や精度などを考えると現段階では実用的とは言えない。

現場 B ではコラム 3 本に対する比抵抗測定を行い、測定結果を图 11 に示す。測定長は 3m で、No.1 (標準品質) コラムでは、3 回の測定 結果はほほ同等で一定值を示し、概ね均質に施工されていると推定で きる。No.2（低品質）コラムでは、GL.-2.0m 付近から比抵抗値が若 干波立つ傾向にあり、原地盤の比抵抗値に近い値を示す箇所も見られ る。No.3 (極低品質) コラムでは、上部の $1.0 \mathrm{~m}$ を除くと哚度方向の ばらつきが非常に大きい。掘出し試験を実施し、GL-2.0m 地点での切 断面を確認したところ、图 12 に示すようにNo.1 コラムでは土塊の混 入は認められず、No.2 では若千の土塊が認められた。No.3 コラムで は、ほとんどが土塊であった。

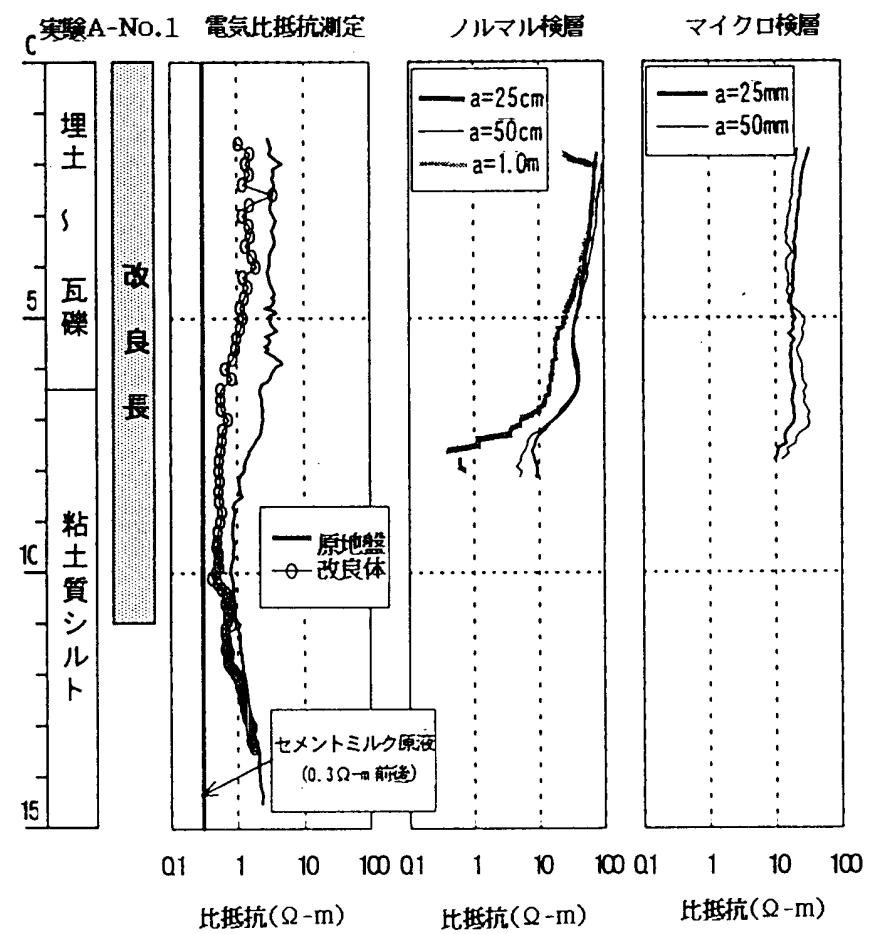

图 10 実駚 A（No. 1）における比抵抗調査結果

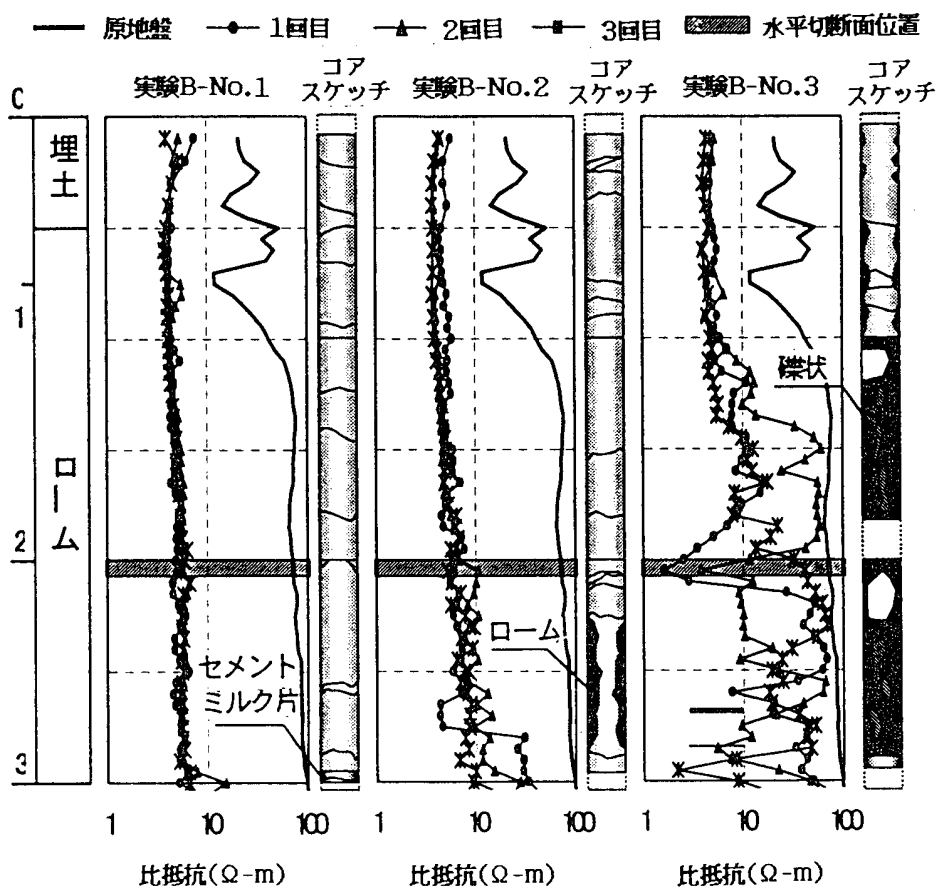

图 11 実跧 Bにおける比抵抗調查拮果 

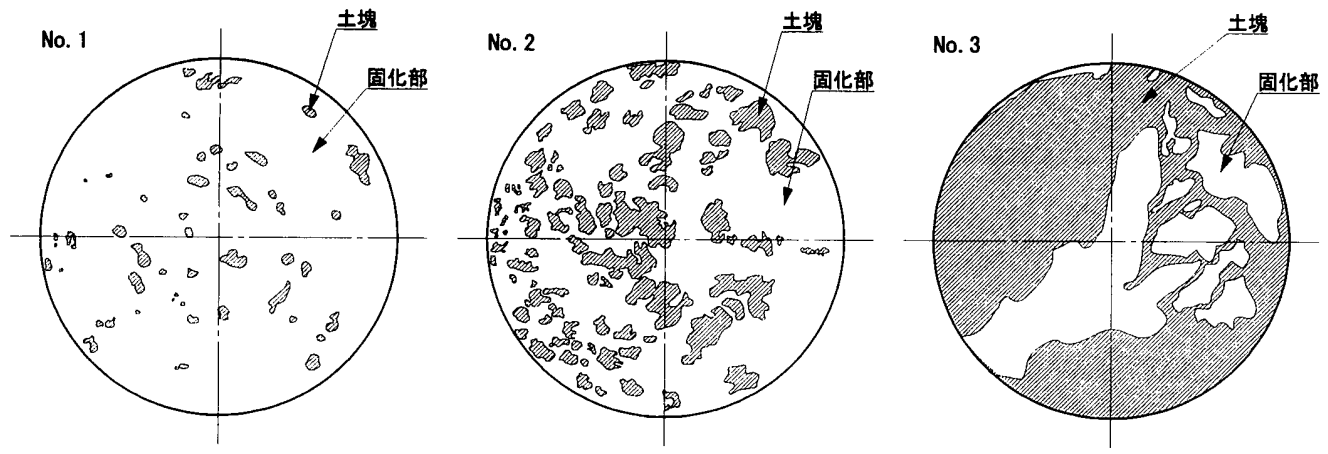

注）水平切断面（深度 2m）において、目視及ひ色彩に基すきき゚ソコン上で面像处理を行ったもの

图 12 実殹 B における水平切断面の土塊混入状況

\section{3 孔内水平コーン貫入䛠硢}

孔内水平コーン貫入試験は、孔壁が滑らかでなく磁・ガラなどを含 むと信頼性がそしいため、実験 A-No.3 の孔壁が比較的滑らかな深度 GL-5.0 11.0m の範囲で実施した。試験結果を图 13 に示す。測定は 深度 $10 \mathrm{~cm}$ 毎、コーン貫入速度は $5.0 \mathrm{~mm} /$ 分程度である。図中にはボ ーリングコアの一軸圧緶強さ（夷測 $\mathrm{q}_{\mathrm{u}}$ ) も併せて示す。途中 GL.-10m 付近で孔壁に凹凸があり測定できない個所があったが、コーン貫入抵 抗值 $\mathrm{q}_{\mathrm{co}}$ から求めた换算 $\mathrm{q}_{\mathrm{u}}$ と実測 $\mathrm{q}_{\mathrm{u}}$ の傾向は图 4 と同様、類似してお り、 $\mathrm{q}_{\mathrm{u}}$ との相関は概初 $\mathrm{q}_{\mathrm{co}}=7 \mathrm{q}_{\mathrm{u}}$ 程度であった。

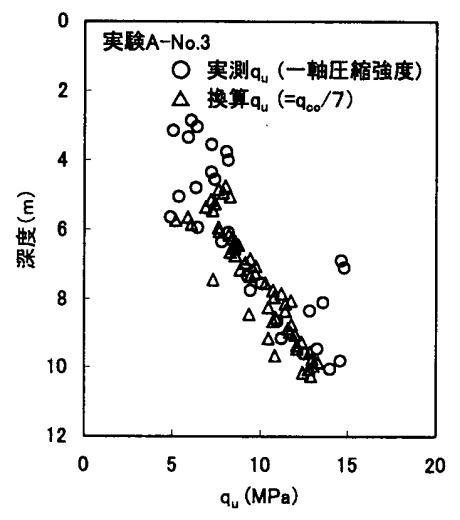

图 13 孔内コーン貫入試跧結果

\section{4 ボアホール映像}

ボアホール映像調查は、 実験 $A 、 B$ とは別地点で実 施した。ボーリング孔内に は掘削時の泥水あるいは 懸濁液が充満しているの で、映像の鮮明度を高める ため孔内の洗浄を行った。 洗浄作業を迅速に進める ため、沈降促進剂を投入し、 30 分程度放置してから撮 影した。图 14 は、映像結 果とボーリングコアのス ケッチ (ボーリング孔壁の 展開図)である。ボアホー ル映像による図面はボー リング孔壁を展開してい る。

ボーリングコアで土塊が
混入している位置の映像は、他の部分と色相が明らかに異なってお り、土塊の色を反映していると考えられる。均質に施工されたコラム であれば、土質によっても異なるが、ある程度は同様の色相と考えら れ、土塊との区別が可能であろう。

\section{5 土塊湿入状況の評洒}

\section{(1) コア採取率調査}

ボーリングコアのコア採取率は表 4 に示しており、実験 B の No.2、 No.3を除くと、いずれも 95\%を上回っており一体に固結していた。

（2）コラムの水平切断面の土塊混入状況

実験 B の 3 本のコラムについて掘出し試験を実施し、媣さ約 $2.0 \mathrm{~m}$ 地 点の水平切断面でポケット型コーン貫入試験とピン貫入試験を行った。 土塊混入率を求めるためパソコン上で画像処理した断面観察結果を图 12 に示す。写真 2 は、ピン貫入による土塊混入率の試験状況である。 表 5 に両試験による土塊混入率を示すが、ピン貫入試験による土塊混 入率は、断面観察結果による土塊混入率とほぼ同等と評価される。ポ ケット型貫入試験は、土塊が多いと試験結果の数值が表せない久点

\section{表 5 水平切断面の土塊湿入事結果}

\begin{tabular}{|c|c|c|c|c|}
\hline \multicolumn{2}{|r|}{ コラムル゚o. } & 1 & 2 & 3 \\
\hline \multirow{3}{*}{$\begin{array}{l}\text { ポケット型 } \\
\text { コーン莫入 }\end{array}$} & 人抵抗10kg以下の測定本数（本） & 7 & 86 & - \\
\hline & 測虏総数 (本) & 405 & 433 & - \\
\hline & 土塊混入率 (\%) & 1.7 & 19.9 & - \\
\hline \multirow{3}{*}{ ピン贯入 } & 土塊と判断したピン本数（本） & 6 & 82 & 255 \\
\hline & 測点総数 (本) & 377 & 377 & 377 \\
\hline & 土塊混入事 (\$) & 1.6 & 21.8 & 67.6 \\
\hline \multicolumn{2}{|c|}{ 断面の钼察により求めた土塊混入事（\%) } & 4.6 & 23.7 & 66 \\
\hline
\end{tabular}

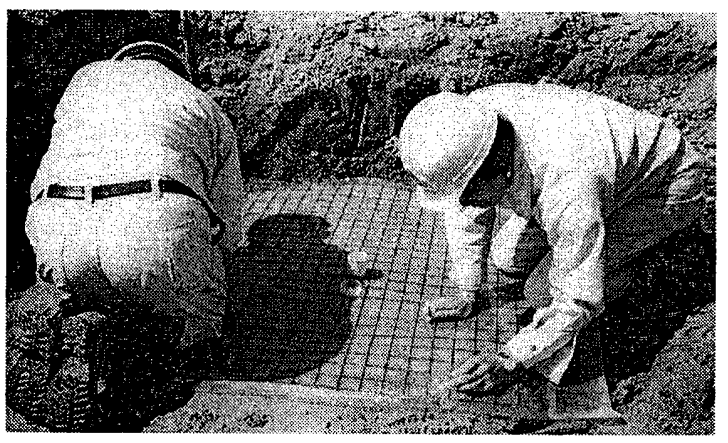

写真 2 ピン貫入試験による土塊湿入车試殹状況 
があるが少ない範囲では同等の評価を与えている。以上の結果から、 径 $1200 \mathrm{~mm}$ のコラムの場合、5 6cm 間隔の格子点上の測点での調査、 即ちコラム断面 $30 \mathrm{~cm}^{2}$ 程度に一力所の調査で土塊混入率が概ね把握で きると思われる。ピン貫入試験は、特別な試験器具を用いずに、現場 で容易に土塊混入率が測定できる特徴があり、水平切断面の筧汼混合 度を詳細に把握するために有用であると考えられる。なお、今回の実 験では、コラム頭部は深部の摜拌状況に係わらず摫汼が良好になって おり、水平切断面の膡拌状況を把握するためには深度に対する配虑も 必要であろう。擋拌中は十分に鯕拌された泥状の混合土が地表に排土 される場合が多いことから、空打ちする場合を除くと、一般に地表付 近は練り返し効果が高いと考えられる。

\section{6 II 試涘}

IT 試験は実験 A、B で実施し、実験 A ではNo.1、2 の他に改良長 および施工条件が同じ実施工コラム 25 本の測定を行った。捨コンが 打設される前のコラム頭部に対して試験を実施するものとし、1 本の コラムに対して 4 回の記録を行い、波形の再現性を確認した。また、 今回実施したコラムに対する評価は、(1)先端反射の有無、(2)先端反射 以外の反射波の有無、に着目し、判定は表 6 に基づいて行った。

\section{表 6 IT 試倹による品貫䛨伍法}

\begin{tabular}{|c|c|}
\hline 判 定 & 条 \\
\hline 报 & 先端反射が明瞕でこれ以外の反射波を含まない \\
\hline 良 & 先端反射が確袏できるがこれ以外の反射を含む \\
\hline 不可 & 先端反射が確想できない \\
\hline
\end{tabular}

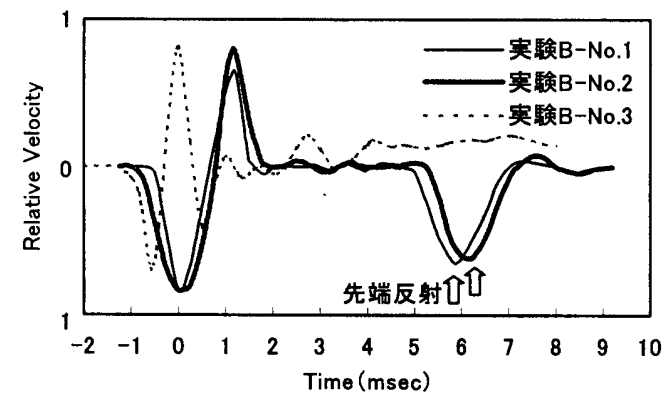

图 15 IT 試殹結果

上記の評価を適用すると、実験 A では、No.1、2 を含む 21 本が“優”、 それ以外はすべて “良”となった。また、実験 B では、低品質コラム では先端反射が確認できず判定は “不可”となり、それ以外の標準品 質及び低品質コラムでは “優” の判定となった。測定結果を图 15 に示 す。実験 B の No3（極低品質コラム）を掘出して確認したところ、コ ラムの最外周はセメントミルクの薄い膜で覆われているが、写真 3 に 示すように内部はほとんど未硬化であった。このため、IT 試験で “不 可”と判定されたコラムに関しては、施工状況や地盤状況を考慮した 詳細検討が必要と考えられる。コラムの最外周部に"薄皮镘頭状"のセ メントミルクの外殼が生じる原因としては、

(1)摜拌翼の水平方向のぶれなどが生じると䚑拌不良な層が生じやす い。

(2)最外周部は中央部と比較して土の動きが半径方向に拘束され穓汼 しにくい。

(3)外周部は摫挥翼による地盤の切削速度が速いので摫找時に土塊を 練り返せずに速く動かし、行き場のないセメントミルクが集まり やすい。

などが考えられる。写真 3 の状況は、地盤や施工によっては生じる 可能性があり、内部を確実に摫䢁するための摫拌条件の検討が重要で
ある。また、掘出し試験で摜拌状況を調べる場合、外観の目視確認だ けでは不十分であり、切断等によるコラム内部の調查が必要不可欠と 考えられる。また、No.2 の低品質コラムは、IT 試験では『優』とな ったものの未改良土塊がかなり含まれていたため、この試験で優とな っても、必ずしも均質な靦拌を意味しないが、No.3 コラムのように反 射が確認できない場合は極端に筧拌が劣る可能性があると考えられる。

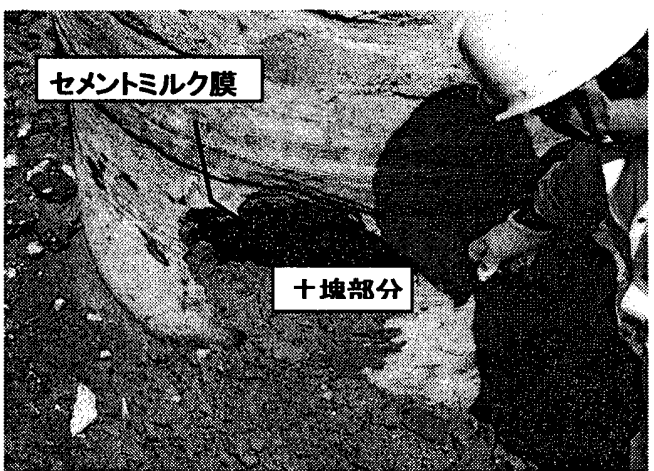

写真 3 極低品貝コラム（実験 B一No. 3）の㓰出試験状況

\section{7 末便化段䐗のソイルセメントの採取}

未硬化段階のソイルセメントの採取試験は、実験 $\mathrm{A}$ の現場において、 No.1 3 以外の改良長 $4 \mathrm{~m}$ のコラムで実施した。写真 4 に图 9 の採取 装置によるソイルセメントの採取状況を示す。試料は全長にわたって 採取され、目視や指圧で確認したところ、一部で土塊の混入が認めら れた。このため、图 9 の装置を施工機械に取り付ければ、施工直後の 擋拌混合状況の目視確認が容易となる。
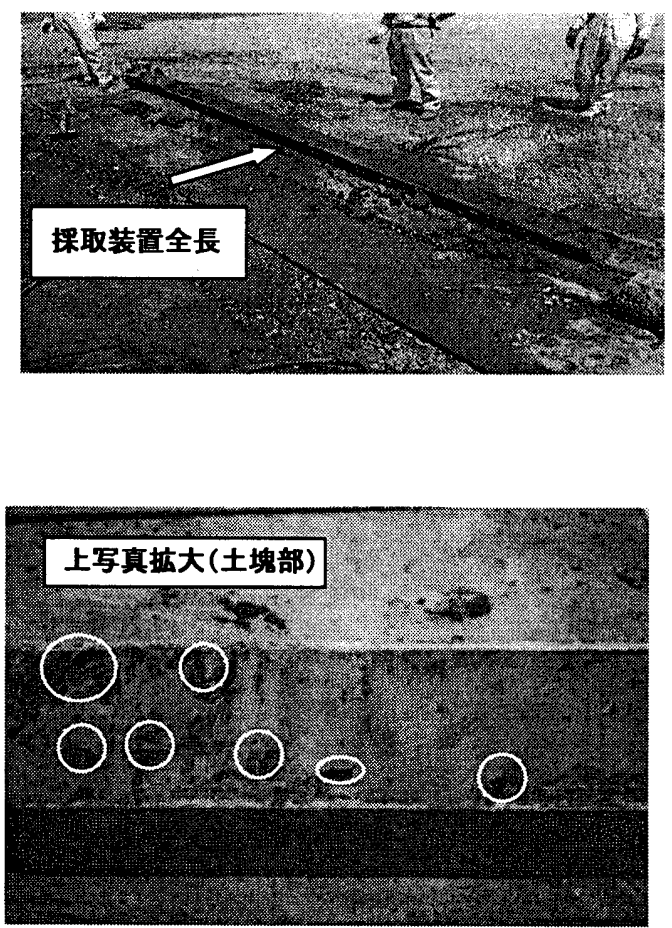

写真 4 末硬化段陼のソイルセメント璪取蓤置による コラム全長の詰料採取状況 


\section{6. コラムの、品貣基準と各種試験の評西}

コラムの品質基準は、設計法により異なると考えられるが、施工範 囲の改良体が一体に固結し、改良効果が確認できる程度のばらつきに 収まっていることが必要である。この観点から、コア強度調查、電気 比抵抗調查、水平断面の土塊混入調査などの意義について考える。

2 章で述べたコア強度と変動俰数に基づく品質基準を考えた場合、 まず、コアの無作為採取を考える上で重要なコア採取率とコア強度の 変動係数 V の関係を知ることが重要である。图 16 は、コア採取率と 変動係数 V の関係を示した図である。各々の点は、土質区分に基づい て同一土質と判断される層内にあるデータから求めた変動保数をプロ ットしたものである。コア採取率が小さいと変動係数のばらつきが大 きくなり、コア採取率が $90 \%$ 以上の場合はV が比較的安定し概ね $30 \%$ 以下を示す。そこで、2 章では、信頼できる品質検査基準を設定する ためには、Vを概ね $30 \%$ 以下とみなすことが前提であることを示した。 $\mathrm{V}$ が $30 \%$ よりかなり大きくなるような混合状態の悪い改良体の場合 は、コア採取率が小さくなると予想されるが、コア試験体を採取でき ていない範囲が多いということであり、悪い部分をはずした形で変動 係数を評価するという、無作為採取の信頼性を満足できていない点を 考慮する必要がある。

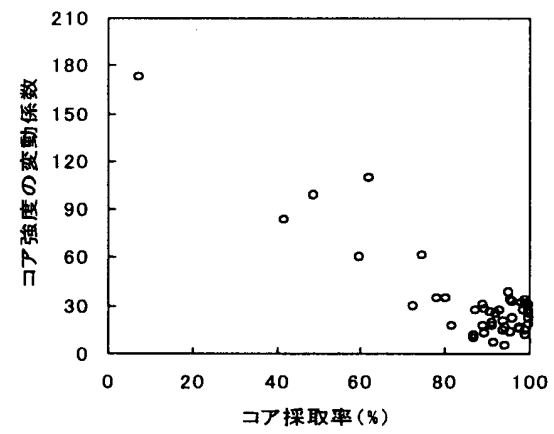

図 16 コア採取率と変動保数の関保

電気比抵抗調査は、ボーリングコアでは評価しにくい挸找混合度の 評価精度を高めることが可能で、先端支持力に期待する設計をする場 合の先端部の掼找状況やコラム頭部の境界部（パイルキャップ梁度付 近、施工中の改良部の盛上がりがあるので不明瞭となる）の僧汼状況 を詳細に把握できる特徽がある。定量的な電気比抵抗調查の適用方法 に関しては、 $\mathrm{m}$ 每の比抵抗の変動係数とコア採取率との関係を考えた。 图 17 は、文献 8)9)10)などのデータをまとめたものであり、土塊混入 率は、(100\%-コア採取率) と同等であることを考虑すると、コア採取 率が 90\%以上期待できるケースでは比抵抗值の变動保数が概ね 30 〜 $40 \%$ 以下であり、これも目安になりうる。なお、比抵抗の変動係数と は、測定距離を $5 \mathrm{~cm}$ として $1 \mathrm{~m}$ 毎の 20 個のデータに対するものであ る。

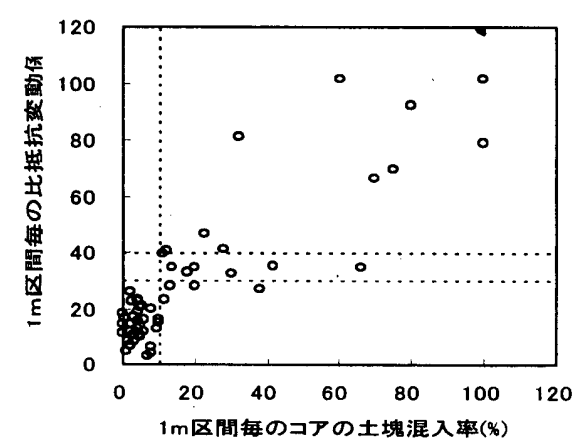

图 17 コアの土塊湿入辛と此抵抗の変動係数の関保
ピン貫入試験などは、摫抖翼の形状や固化材液の吐出位置などの違 いによる水平方向の靦拌状況の变化を詳細に把握することができる特 徵がある。定量的なピン貫入試験による土塊混入率の評価に関しては、 実験 B の低品質及び極低品質コラムを除くと、コア強度、コア採取率、 電気比抵抗など他の評価法で特に支障ないコラムでは、土塊混入率が いずれも数\%であった。深度方向のコア採取率としては $90 \%$ 、即ち土 塊混入率としては概小 $10 \%$ 以下としていることを考え併せると、水平 切断面でもボーリングコアと同様、土塊混入率としては $10 \%$ 程度とす ることが望ましい。

IT 試験はコラム群としての施工の確実性を簡便に把挃できる特徵 がある。この方法は、個々の試験を定量的に評価するより、多数のコ ラムの相対的な品質評価や極端に品質が劣る可能性のあるコラムの推 定が可能であろう。成層状況などが複雑な地盤や経験の乏しい特殊な 地盤に対する適用性を知るために、特に有用と考える。

\section{7. まとめ}

本研究は、コラムの品質評価法に関するものであり、(1)電気比抵抗 測定、(2)水平切断面の土塊混入状況の評価、(3)IT 試験などによる評価 技術の有用性や意義を明確にすることができた。

今回の実験では、様々の調査法の特徽や適用範囲の把握を目的とし たが、改良体の品質は地盤や施工のわずかな違いで大きく異なること がある。現状では、経験・実績などにより砂質土〜粘性土〜ロームの 順に摫汼しにくいと考えられているが、自然含水比、液塑性限界、セ メントミルク量などによって異なる可能性がある。今後は摜汼のしや すさと地盤条件の関保を定量的に把握し、品質評価試験における地盤 条件の合理的な設定方法を検討する予定である。

なお、上記は『基礎工法（機械式深層混合処理工法）の性能評価に 関する研究委員会 : (社) 建築研究振興協会』の研究成果の一部を含む ものである。ご協力いただいた方々に梁く感謝する次第である。

\section{《参考文献》}

1)建築物のための改良地盤の設計及び品質管理指針, 編集協力建築研究所 日 本建筑センター 1997

2)小堀・渡辺他: 機械式深層㩧押混合工法に関する性能評価技術の開発 (その 1) （その 6), 第 35 回地盤工学研究発表会 pp.443 454, 2000.6 3)田村・藤井他：電気比抵抗を用いた改良体の品質評価に関する現場実験,日本 建築学会論文報告集 No.5 pp95 100，2000

4)田村・渡辺他：深層混合処理工法を対象とした性能評価の考え方，土と基礎 Vol.48 No.5 pp.9 12, 2000.5

5)孔壁展開画像観察記録および地質構造解析システ 一BIP System一， BIPS 技術研究会 URL; http://www.bips.gr.jp/

6)太田・渡辺他 : 機械式深層㩲扫工法におけるソイルセメントコラムの土塊混入 試験ーピン貫入による土塊混入率試釱の適用性一、日本建築学会大会学術講演 概要集、pp499 500，2000

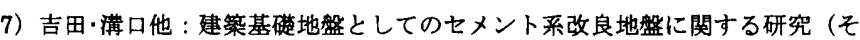
の 29）改良土の試料採取方法と一軸圧縮強度、日本建築学会大会学術講演梗概 集, pp871 872,1995

8)野村、溝口他:電気比抵抗法を用いた現位固造成杭の品質評価に関する研究(そ の 7 ソイルセメントコラムの品質に関する現場実験)、第 32 回地盤工学研究発 表（熊本）,pp1677〜1678,1997

9)溝口、田村他 : 電気比抵抗法によるソイルセメントコラムの品質評価事例、日 本建築学会大会学術講演梗概集（九州）,pp619 620,1998

10)小川・酒井他 : 電気比抵抗と CT スキャンによる改良コラムの品質評価、建築 基硌の設計施工に関する研究資料 5 シンポジューム論文集 実務に見る地盤 改良工法の技術的諸問題、日本建築学会基硴構造運営委員会、pp47〜52,1999 11)山本 : 孔壁垂直コーン貫入試験の室内試験に関する一考察、第 23 回地盤工 学研究発表会、」、pp.165 166,1988.6

(2001年 1 月31日原稿受理，2001年 7 月 30 日採用決定） 